\title{
Enhanced Antibacterial Activity of Lactoperoxidase-Thiocyanate-Hydrogen Peroxide System in Reduced-Lactose Milk Whey
}

\author{
Ahmad Ni'matullah Al-Baarri $\mathbb{D}^{1},{ }^{1}$ Novia Tri Damayanti, ${ }^{2}$ \\ Anang Mohamad Legowo, ${ }^{2}$ İsmail Hakkı Tekiner, ${ }^{3}$ and Shigeru Hayakawa ${ }^{4}$ \\ ${ }^{1}$ Food Technology Department, Faculty of Animal and Agricultural Sciences, Diponegoro University, Indonesia \\ ${ }^{2}$ Animal Sciences Department, Faculty of Animal and Agricultural Sciences, Diponegoro University, Indonesia \\ ${ }^{3}$ Gastronomy Department, School of Applied Sciences, Istanbul Gelişim University, Turkey \\ ${ }^{4}$ Applied Biological Sciences, Faculty of Agriculture, Kagawa University, Japan \\ Correspondence should be addressed to Ahmad Ni'matullah Al-Baarri; albari@live.undip.ac.id
}

Received 13 November 2018; Revised 3 March 2019; Accepted 3 April 2019; Published 23 April 2019

Academic Editor: Amy Simonne

Copyright (C) 2019 Ahmad Nimatullah Al-Baarri et al. This is an open access article distributed under the Creative Commons Attribution License, which permits unrestricted use, distribution, and reproduction in any medium, provided the original work is properly cited.

\begin{abstract}
The product of the lactoperoxidase system (LPOS) has been developed as a preservative agent to inhibit foodborne bacteria, but its action was, heretofore, limited to several original compounds in milk. This research was conducted to analyze the application of the lactoperoxidase system against Escherichia coli in fresh bovine milk and its derivative products to determine the strength of antibacterial activity. Lactoperoxidase was purified from bovine whey using the SP Sepharose Big Beads Column. The enzymatic reaction involving lactoperoxidase, thiocyanate, and hydrogen peroxide was used to generate the antibacterial agent from LPOS. This solution was then added to milk, skimmed milk, untreated whey, reduced-LPO whey, reduced-lactose whey, and high-lactose solution containing E. coli at an initial count of $6.0 \mathrm{log}$ CFU/mL. LPOS showed the greatest reduction of bacteria (1.68 \pm 0.1 $\log \mathrm{CFU} / \mathrm{mL}$ ) in the reduced-lactose whey among the products tested. This result may lead to a method for enhancement of the antimicrobial activity of LPOS in milk and derived products.
\end{abstract}

\section{Introduction}

Lactoperoxidase (LPO) was developed to inhibit the growth of foodborne pathogens in various foods and thus improve their shelf life $[1,2]$. Lactoperoxidase derived from bovine milk has been shown to generate beneficial effects as a bactericidal and bacteriostatic agent $[1,3]$. The lactoperoxidase system consists of three primary components: lactoperoxidase enzyme, thiocyanate, and hydrogen peroxide. This system generates hypothiocyanite, an active compound against Gram-positive and Gram-negative bacteria, including Escherichia coli $[4,5]$. The lactoperoxidase system (LPO system) has attracted the attention of scientists as a natural biopreservative with generally recognized as safe (GRAS) status [6]. Hypothiocyanite, a product of LPOS, has been recognized as a safe antibacterial agent without negative effects on human health $[7,8]$.

Biopreservation using the LPO system could offer an additional hurdle to improve the shelf life of various food products such as fruit [9], chicken meat [10], duck meat [11], cheese [12], and local food products such as dangke $[2,13]$. However, slight inhibition of pathogenic bacteria also appeared in fresh milk. Other researchers reported the slight reduction of below $1 \log \mathrm{CFU} / \mathrm{ml}$ in fresh milk treated with the lactoperoxidase system [14]. It was understood that lactoperoxidase antimicrobial activity might be enhanced using lysozyme [2], beta carotene [15, 16], ectoine [17], alpha tocopherol [18], and chitosan [19], but it was inhibited by several compounds such as hydrogen peroxide and thiocyanate in excess amounts [20-22] and indigenous milk 
compounds such as casein [23] and saccharides [24]. It was then presumed that the removal of casein and lactose from the milk enabled the use of lactoperoxidase to reduce the population of bacteria in fresh milk.

It was reported that lactose reduces LPO activity by $38 \%$ because the sugar molecules interact with the heme cavity of the LPO $[24,25]$. The association of sugar molecules with the heme cavity physically blocked the substrate-binding site, thereby resulting in the prevention of the interaction of substrate with the heme iron [21]. This research aims to use LPOS to reduce pathogenic bacteria in milk and its derived products after removal of lactose and casein from milk. This research will provide beneficial information to apply LPOS in milk and derived products.

\section{Materials and Methods}

2.1. Materials. SP Sepharose ${ }^{\mathrm{TM}}$ Big Beads (Lot No. 10081054) was purchased from GE Healthcare Bio-Sciences AB, Sweden. Microbial rennet was purchased from Prodinvest Group, Russia. Deoxycholate hydrogen sulfide lactose agar (DHL) (Lot No. 395-00461) was obtained from Shinnihonseiyaku Co., Ltd., Japan. ABTS was purchased from Wako Pure Chemical Industry, Japan. Bovine milk was freshly obtained from the experimental farm at the Faculty of Animal and Agricultural Science, Diponegoro University, Semarang, Indonesia. Culture stock of Escherichia coli FNCC 0009 was purchased from the Faculty of Agricultural Technology, Gadjah Mada University, Yogyakarta, Indonesia. A spectrophotometer (Mini UV-1240, Shimadzu, Japan) was used for the Bradford protein analysis and enzyme activity. Sterile syringe filters (Lot No. SF2030813) were purchased from Axiva Sichem Biotech Delhi, India. All chemicals used in this study were of analytical grade.

2.2. Preparation of Whey, Reduced-Lactose Whey, and HighLactose Solution. Whey was obtained using fresh bovine milk that was treated with $0.02 \%(\mathrm{w} / \mathrm{v})$ rennet. Through these treatments, $1 \mathrm{~L}$ of fresh bovine milk was converted into 800 $\mathrm{mL}$ of whey. Casein was removed using a sterile filter cloth; lactose removal of whey was carried out by dialysis. Untreated whey was dialyzed to produce reduced-lactose whey, and the solution eluted from the dialysis membrane was collected as high-lactose solution.

2.3. Purification of LPO from Whey. The procedure for immobilization of LPO from whey was conducted according to the method of previous researchers [25], with minor modifications. SP Sepharose ${ }^{\mathrm{TM}}$ Big Beads (SPBB) was used as the matrix for LPO purification from bovine whey. Whey was applied on a glass column $(2 \times 17 \mathrm{~cm})$ filled with $17 \mathrm{~g}$ of SPBB. Preparation of SPBB was initiated by washing with $300 \mathrm{~mL}$ pure water and $300 \mathrm{~mL}$ of $0.1 \mathrm{mM}$ phosphate buffer (PB) of $\mathrm{pH} 6.8$ containing $1 \mathrm{M} \mathrm{NaCl}$ to remove unnecessary compounds. After the whey was applied to the column, the resin was washed with $100 \mathrm{~mL} 0.4 \mathrm{mM} \mathrm{NaCl}$ in $0.1 \mathrm{mM}$ phosphate buffer of $\mathrm{pH} 7.0$ using a fraction collector $(10 \mathrm{~mL}$ per tube). The purity of the derived LPO was checked by
Sodium Dodecyl Sulfate-Polyacrylamide Gel Electrophoresis (SDS-PAGE), using the method of a previous researcher [26]. The protein solution was filtered through a $0.22 \mu \mathrm{m}$ syringe filter unit. The purified LPO was stored at $-20^{\circ} \mathrm{C}$. The LPO purification was done for multiple times until the band of LPO showed a clear image using the SDS-PAGE analysis.

2.4. Determination of Protein Concentration. Protein content was analyzed using the Coomassie Brilliant Blue reagent [27]. The protein standard was determined using bovine serum albumin.

2.5. Inoculum Preparation. The inoculum was prepared following the method of Lang [28] with minor modifications. Before each experiment, stock cultures of E. coli FNCC 0009 were streaked onto Nutrient Broth. Cultures were incubated at $39^{\circ} \mathrm{C}$ for $24 \mathrm{~h}$.

2.6. Determination of LPO Activity. LPO activity was assayed using the method of Al-Baarri [24]. A $450 \mu$ l aliquot of 1.0 $\mathrm{mM}$ ABTS in $10 \mathrm{mM}$ acetate buffer $(\mathrm{pH} 4.4)$ and $450 \mu \mathrm{l}$ $0.55 \mathrm{mM} \mathrm{H}_{2} \mathrm{O}_{2}$ in pure water were poured into the cuvette. Immediately, $50 \mu \mathrm{l}$ of LPO was added to the cuvette. The increase in absorbance at $412 \mathrm{~nm}$ was measured for 1 minute. One unit of LPO enzymatic activity was expressed as the amount of enzyme needed to oxidize $1 \mu \mathrm{mol} \mathrm{ABTS} \mathrm{min}^{-1}$. The molar extinction coefficient of ABTS at $412 \mathrm{~nm}$ was 32,400 $\min ^{-1} \mathrm{~cm}^{-1}$.

2.7. Determination of Antibacterial Activity. Antibacterial activity was measured using the method previously described by Touch [10] with modifications. The LPO system, composed of $3.0 \mathrm{U} / \mathrm{ml} \mathrm{LPO}, 0.9 \mathrm{mM} \mathrm{KSCN}$, and $0.9 \mathrm{mM} \mathrm{H}_{2} \mathrm{O}_{2}$, was incubated for 1 hour at room temperature to generate the antibacterial compound. The LPOS solution was then added to the milk and its derivative products, which were inoculated with E. coli at approximately $10^{7} \mathrm{CFU} / \mathrm{mL}$. Each mixture was incubated in a water bath shaker at $30^{\circ} \mathrm{C}$. Controls with 0.1 $\mathrm{mM} \mathrm{PB}$ of $\mathrm{pH} 7.0$ instead of the milk were subjected to the same treatment as the samples. Serial dilutions in sterilized pure water were prepared to obtain countable numbers of bacteria. Counts were obtained by spreading $100 \mu \mathrm{L}$ of each mixture onto triplicate plates of DHL. The plates were incubated at $37^{\circ} \mathrm{C}$ for $24 \mathrm{~h}$. Colony forming units (CFU) were enumerated in plates containing 30-300 colonies, and cell concentration was expressed as $\log \mathrm{CFU} / \mathrm{mL}$.

2.8. Determination of Lactose Content in Whey. Lactose content in whey was determined by using a refractometer. The ability of the refractometer to provide accurate measurements was indicated by how closely the test results matched those obtained with the MilkoScan. This method was adapted from Chigerwe [29]. Whey obtained by the previously mentioned method of whey purification was analyzed by means of the MilkoScan 203 and refractometer, resulting in a mean bias of $94 \pm 1.92 \%$. Lactose concentrations were determined by comparing the value obtained by the refractometer with a standard curve generated with lactose. The regression 
equation with $\mathrm{R}^{2}=0.97$ was used to determine lactose concentration.

2.9. Data Analysis. The analyses for antimicrobial activity and lactose content were carried out in triplicate from 3 independent experiments; then they were analyzed using descriptive analysis to explain their changes. Data are showed as means \pm standard error of the mean. Statistical significance was calculated using the GraphPad Prism statistical software (San Diego, USA). The ANOVA analysis was used to decide the significance at $P$ values of less than 0.05 .

\section{Result and Discussion}

3.1. Purification of LPO and Characteristics of the Purified Protein. Lactoperoxidase is known as an antimicrobial agent in milk, saliva, and tears because of its inhibitory action on bacteria through the oxidation reaction involving thiocyanate and hydrogen peroxide $[30,31]$. LPO is a glycoprotein consisting of a single polypeptide chain with a molecular weight of $78 \mathrm{kDa}$ (Golhefors and Marklundi, 1975; Jacob et al., 2000). The purification process of LPO from bovine whey was conducted at $10^{\circ} \mathrm{C}$ to provide optimum binding of LPO to the SP Sepharose matrix [30]. Therefore, this research used SP Sepharose to bind LPO in whey.

A high peak of LPO activity was detected from fraction numbers 1-5, with values in the range of 80-93 units (Figure 1). No significant LPO activity was detected in fractions 6-9. Each fraction was then applied to SDS-PAGE to determine its purity. As a result, several bands were detected in fractions 1-3 (Figure 2). However, fractions 4 and 5 showed a single band with minor other proteins, indicating that purity of LPO was high in these fractions. Therefore, fractions 4 and 5 were mixed and their activity was calculated, obtaining 94 and $93 \mathrm{U} / \mathrm{ml}$, respectively. Since previous application of LPO for reducing $S$. enteritidis only required $4.5 \mathrm{U} / \mathrm{ml}$ [16], the lactoperoxidase obtained by this purified LPO sufficiently fulfills the need for LPO application in the next set of experiments. Prior to enzyme collection in a $1.5 \mathrm{ml}$ tube, the mixed fraction was sterilized using a $0.22 \mu \mathrm{m}$ syringe filter, and then the enzyme was stored at $-20^{\circ} \mathrm{C}$.

3.2. Antibacterial Activity of the LPO System from Bovine Milk. This research used $7.0 \pm 0.10 \log \mathrm{CFU} / \mathrm{ml}$ of E. coli as the initial population. The incubation times were set to 1 and 4 hours at $30^{\circ} \mathrm{C}$ (Figure 3 ). It can be seen that LPOS remarkably reduced the population of $E$. coli in $\mathrm{PB}$ from the initial count to $5.58 \pm 0.10 \log \mathrm{CFU} / \mathrm{mL}$, indicating a reduction of $1.42 \pm 0.03 \log \mathrm{CFU} / \mathrm{mL}$ after 4 hours of incubation. These findings imply that inhibitory effects on the antibacterial activity of LPO tend to increase with the higher duration of incubation. However, statistical analysis showed that there were no significant differences $(P<0.05)$ in the antibacterial activity among treatments. This might be due to the high population of initial bacteria that was used in this research. The incubation time plays a remarkable role in bacterial reduction that could be seen by the increase in the antibacterial activity at $4 \mathrm{~h}$ of incubation. As can be

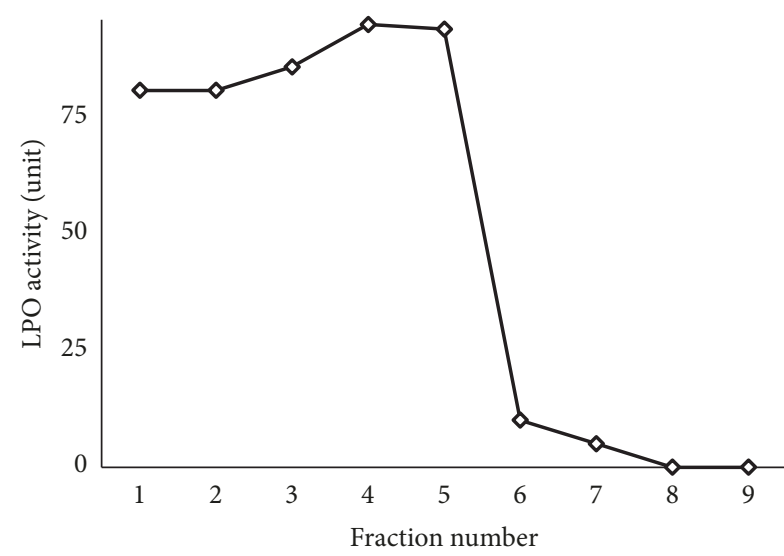

FIGURE 1: LPO activity in nine fractions obtained from the elution of $0.4 \mathrm{mM} \mathrm{NaCl}$ in $0.1 \mathrm{mM}$ phosphate buffer of $\mathrm{pH} 7.0$ through column containing Sepharose ${ }^{\mathrm{TM}}$ Big Beads.

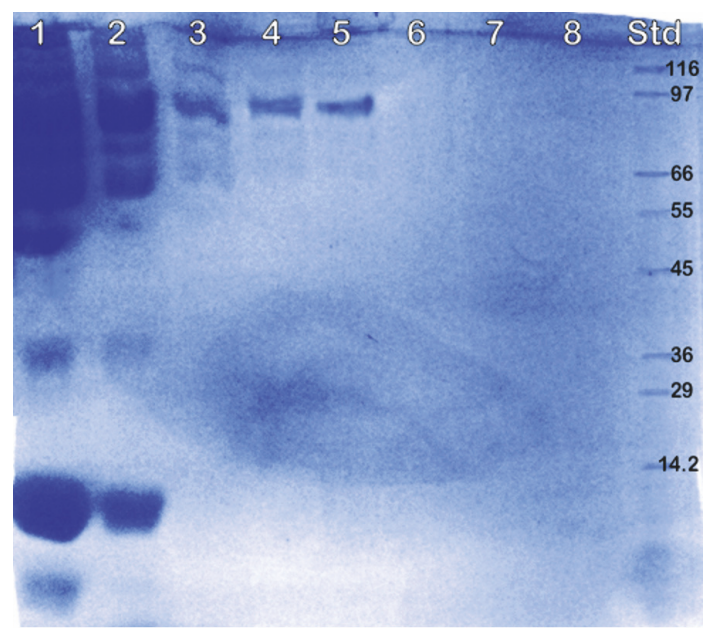

FIGURE 2: SDS-PAGE profile of nine fractions that were eluted from column packing Sepharose ${ }^{\mathrm{TM}}$ Big Beads. Lanes 1 to 8 were the samples from fractions 1 to 8 .

seen in control, antibacterial activity showed less than 0.1 $\log \mathrm{CFU} / \mathrm{mL}$ in the sample with a 1-hour incubation and then elevated to $1.42 \pm 0.04 \mathrm{CFU} / \mathrm{mL}$ at $4 \mathrm{~h}$ incubation. Opstal [32] reported a greater reduction of $E$. coli by LPOS (2.2 $\log \mathrm{CFU} / \mathrm{mL}$ ) from the initial count of $6.0 \mathrm{CFU} / \mathrm{mL}$ during 6 hours of incubation at $20^{\circ} \mathrm{C}$. These differences between studies might have been due to differences in the bacterial load and incubation time.

Bacterial reductions in whole milk, skimmed milk, and untreated whey were less than in the control $(<1.0$ log $\mathrm{CFU} / \mathrm{mL}$ ), possibly due to the presence of casein and lactose in milk and whey. Casein is the abundant component in milk protein that might protect substrate microorganisms from absorption of the antimicrobial component, thus weakening the inhibitory effect on bacteria [23]. It is known that bactericidal effects of $\mathrm{OSCN}^{-}$compounds from LPOS are key to kill bacteria by disrupting sulfhydryl groups (-SH) on proteins from the bacterial cytoplasmic membrane [24], 


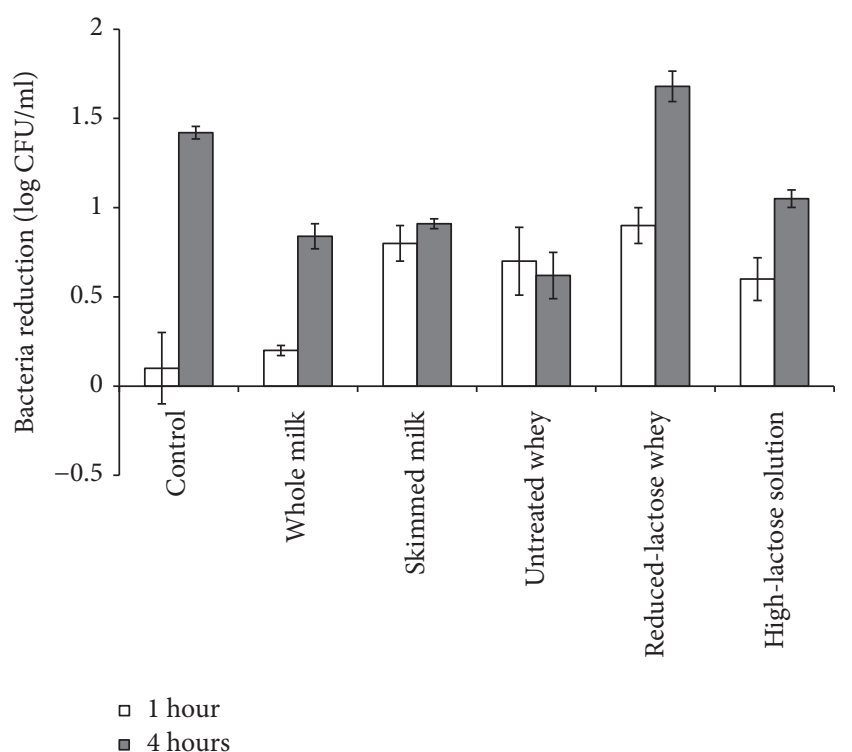

FIgURE 3: Antibacterial effect of LPOS against E.coli in milk and derivative products. This number was calculated from the initial population of $7.0 \pm 0.10 \log \mathrm{CFU} / \mathrm{ml}$. The solution containing E. coli and LPOS was incubated for 1 and 4 hours in $30^{\circ} \mathrm{C}$. Values are means $\pm \operatorname{SE}(n=3)$.

so the interaction between the sulfhydryl group and $\mathrm{OSCN}^{-}$ might be hindered, resulting in the weakening of antibacterial action. Inhibition of LPOS action could also occur due to hydrogen peroxide released from bacteria [23].

The lactose content in untreated whey was $1.82 \pm 0.20 \%$, and after dialysis, it was reduced to $0.69 \pm 0.10 \%$ (Table 1 ). Results from the statistical study showed that the reduction exhibited no significant difference $(P<0.05)$, but it showed $62 \%$ reduction resulting in the 2.7 times antibacterial activity enhancement of LPO from $0.62 \pm 0.20$ to $1.68 \pm 0.10$ that clearly indicated inhibition of antibacterial activity of LPOS by lactose (Figure 3 ). These results were corroborated by those of previous researchers [10], finding that LPOS was unable to reduce the significant amount of $S$. enteritidis in whole milk. Saccharides including lactose were potent inhibitors of lactoperoxidase activity and showed kinetic inhibition of 3.20 \pm 0.52 [24]. Therefore, the reduction of the lactose amount in milk might increase the action of LPOS against the growth of bacteria. The inhibition of LPOS by lactose might be due to the weakening of enzymatic activity of LPO, since saccharides are a nonspecific stabilizer of protein that allows for direct interaction between carbohydrate and protein molecules through hydrogen bond formation, resulting in the reduction of enzymatic activity [33]. In addition, as reported by previous researchers [34], the carboxylic group might bind to the side chain of 2-Glu258 to form a strong hydrogen bond resulting in the inability of a natural substrate such as thiocyanate to bind to LPO.

It was described that lactose had performed as an LPO inhibitor; therefore the lactose conversion into another compound was suggested. Previous researchers [35] applied lactose reduction using lactose oxidase to generate an $\mathrm{H}_{2} \mathrm{O}_{2}$ compound resulting in the enhancement of antimicrobial
TABLE 1: Lactose content in untreated whey, reduced-lactose whey, and high-lactose solution.

\begin{tabular}{lc}
\hline Materials & Lactose content (\%) \\
\hline Untreated whey & $1.82 \pm 0.20$ \\
Reduced-lactose whey & $0.69 \pm 0.10$ \\
High-lactose solution & $2.05 \pm 0.30$ \\
\hline
\end{tabular}

Values are means \pm SE $(n=5)$.

function of LPOS; however the avoidance of lactose binding to the specific site of LPO might be required since lactose may still provide beneficial effect to the nutrient content of a dairy product. However, in order to achieve the practical application in the dairy industry, this research may provide the novelty with clear explanation that the reduction of lactose content is strongly suggested to exhibit the beneficial impact on the shelf life of dairy products.

\section{Conclusion}

This research indicated that LPOS had moderate antibacterial effects on E. coli in whole milk, skimmed milk, and whey. Lactose reduction from whey remarkably enhanced bactericidal activity. LPOS can effectively act as an antibacterial reagent in reduced-lactose dairy products.

\section{Data Availability}

The authors state that the data in this article were obtained as naturally as possible with the proper replication. The authors also state that the previously reported "lactoperoxidase-thiocyanate-hydrogen peroxide system" was used to support this study and is available at http://doi.org/10.3923/ijds.2014.116.123 and https://doi.org/ 10.4315/0362-028X.JFP-10-184. These prior studies are cited at relevant places within the text as references: [13] Rasbawati, A.N. Al-Baarri, A.M. Legowo, V.P. Bintoro, B. Dwiloka, Total bacteria and $\mathrm{pH}$ of dangke preserved using natural antimicrobial lactoferrin and lactoperoxidase from bovine whey, International Journal of Dairy Science, $9 \mathrm{pp}$. 116-123, 2014; [24] A.N. Al-Baarri, M. Hayashi, M. Ogawa, S. Hayakawa, Effects of mono- and di-saccharides on the antimicrobial activity of bovine lactoperoxidase system, Journal of Food Protection, 74 pp. 134-139, 2011.

\section{Conflicts of Interest}

The authors declare that they have no conflicts of interest regarding the publication of this paper.

\section{Acknowledgments}

Financial assistance from the Ministry of Research, Technology and Higher Education of the Republic of Indonesia?s Grant to conduct this research is gratefully acknowledged. 


\section{References}

[1] C. Abbes, A. Mansouri, and A. Landoulsi, "Synergistic effect of the lactoperoxidase system and cinnamon essential oil on total flora and salmonella growth inhibition in raw milk," Journal of Food Quality, vol. 2018, Article ID 8547954, 6 pages, 2018.

[2] A. N. Al-Baarri, A. M. Legowo, S. K. Arum, and S. Hayakawa, "Extending shelf life of indonesian soft milk cheese (dangke) by lactoperoxidase system and lysozyme," International Journal of Food Science, vol. 2018, Article ID 4305395, 7 pages, 2018.

[3] C. Abbes, M. Ahlem, H. Mariem, and L. Ahmed, "Optimizing antimicrobial activity of the bovine lactoperoxidase system against Salmonella enterica Hadar, a causative agent of human gastroenteritis in Tunisia," African Journal of Microbiology Research, vol. 7, no. 22, pp. 2719-2723, 2013.

[4] M. Kennedy, A.-L. O’Rourke, J. McLay, and R. Simmonds, "Use of a ground beef model to assess the effect of the lactoperoxidase system on the growth of Escherichia coli O157:H7, Listeria monocytogenes and Staphylococcus aureus in red meat," International Journal of Food Microbiology, vol. 57, no. 3, pp. 147-158, 2000.

[5] C. Garcia-Graells, C. Valckx, and C. W. Michiels, "Inactivation of Escherichia coli and Listeria innocua in milk by combined treatment with high hydrostatic pressure and the lactoperoxidase system," Applied and Environmental Microbiology, vol. 66, no. 10, pp. 4173-4179, 2000.

[6] O. O. Alegbeleye, J. T. Guimarães, A. G. Cruz, and A. S. Sant'Ana, "Hazards of a 'healthy' trend? An appraisal of the risks of raw milk consumption and the potential of novel treatment technologies to serve as alternatives to pasteurization," Trends in Food Science \& Technology, vol. 82, pp. 148-166, 2018.

[7] F. Bafort, O. Parisi, J.-P. Perraudin, and M. H. Jijakli, "Mode of action of lactoperoxidase as related to its antimicrobial activity: a review," Enzyme Research, vol. 2014, Article ID 517164, 13 pages, 2014.

[8] H. Neetoo and F. Mahomoodally, "Use of antimicrobial films and edible coatings incorporating chemical and biological preservatives to control growth of Listeria monocytogenes on cold smoked salmon," BioMed Research International, vol. 2014, Article ID 534915, 10 pages, 2014.

[9] M. Cissé, J. Polidori, D. Montet, G. Loiseau, and M. N. DucampCollin, "Preservation of mango quality by using functional chitosan-lactoperoxidase systems coatings," Postharvest Biology and Technology, vol. 101, pp. 10-14, 2015.

[10] V. Touch, S. Hayakawa, S. Yamada, and S. Kaneko, "Effects of a lactoperoxidase-thiocyanate-hydrogen peroxide system on Salmonella enteritidis in animal or vegetable foods," International Journal of Food Microbiology, vol. 93, no. 2, pp. 175-183, 2004.

[11] V. P. B. S. K. Arum, A. N. Al-Baarri, F. Wahono, and A. R. C. Utomo, "Microbiological analysis of fresh duck meat stored in lactoperoxidase system solution," in Proceedings of the 2nd International Student Conference on Food Science and Technology: Global Insight for the Future of Food Production, November 2014.

[12] Y. Amornkul and D. R. Henning, "Utilization of microfiltration or lactoperoxidase system or both for manufacture of Cheddar cheese from raw milk," Journal of Dairy Science, vol. 90, no. 11, pp. 4988-5000, 2007.

[13] Rasbawati, B. Dwiloka, A. N. Al-Baarri, A. M. Legowo, and V. P. Bintoro, "Total bacteria and $\mathrm{pH}$ of Dangke preserved using natural antimicrobial lactoferrin and lactoperoxidase from bovine whey," International Journal of Dairy Science, vol. 9, no. 4, pp. 116-123, 2014.

[14] V. Y. Villa, A. M. Legowo, V. P. Bintoro, and A. N. Al-Baarri, "Quality of fresh bovine milk after addition of Hypothiocyaniterich-solution from Lactoperoxidase system," International Journal of Dairy Science, vol. 9, no. 1, pp. 24-31, 2014.

[15] A. N. Al-Baarri, A. M. Legowo, S. Hayakawa, and M. Ogawa, "Enhancement Antimicrobial Activity of Hyphothiocyanite Using Carrot Against Staphylococcus Aureus and Escherichia Coli," Procedia Food Science, vol. 3, pp. 473-478, 2015.

[16] M. Hayashi, S. Naknukool, S. Hayakawa, M. Ogawa, and A.B. A. Ni'Matulah, "Enhancement of antimicrobial activity of a lactoperoxidase system by carrot extract and $\beta$-carotene," Food Chemistry, vol. 130, no. 3, pp. 541-546, 2012.

[17] M. B. Boroujeni and H. Nayeri, "Stabilization of bovine lactoperoxidase in the presence of ectoine," Food Chemistry, vol. 265, pp. 208-215, 2018.

[18] S. Shokri and A. Ehsani, "Efficacy of whey protein coating incorporated with lactoperoxidase and $\alpha$-tocopherol in shelf life extension of Pike-Perch fillets during refrigeration," LWT-Food Science and Technology, vol. 85, pp. 225-231, 2017.

[19] C. Mohamed, K. A. Clementine, M. Didier, L. Gérard, and D.-C. Marie Noëlle, "Antimicrobial and physical properties of edible chitosan films enhanced by lactoperoxidase system," Food Hydrocolloids, vol. 30, no. 2, pp. 576-580, 2013.

[20] A. K. Singh, N. Singh, M. Sinha et al., "Binding modes of aromatic ligands to mammalian heme peroxidases with associated functional implications. Crystal structures of lactoperoxidase complexes with acetylsalicylic acid, salicylhydroxamic acid, and benzylhydroxamic acid," The Journal of Biological Chemistry, vol. 284, no. 30, pp. 20311-20318, 2009.

[21] A. K. Singh, N. Singh, S. Sharma et al., "Inhibition of lactoperoxidase by its own catalytic product: Crystal structure of the hypothiocyanate-inhibited bovine lactoperoxidase at 2.3Å resolution,” Biophysical Journal, vol. 96, no. 2, pp. 646-654, 2009.

[22] A. K. Singh, R. P. Kumar, N. Pandey et al., "Mode of binding of the tuberculosis prodrug isoniazid to heme peroxidases: Binding studies and crystal structure of bovine lactoperoxidase with isoniazid at 2:7 å resolution,” The Journal of Biological Chemistry, vol. 285, no. 2, pp. 1569-1576, 2010.

[23] F. A. Fonteh, A. S. Grandison, and M. J. Lewis, "Factors affecting lactoperoxidase activity," International Journal of Dairy Technology, vol. 58, no. 4, pp. 233-236, 2005.

[24] A. N. Al-Baarri, M. Hayashi, M. Ogawa, and S. Hayakawa, "Effects of mono-and disaccharides on the antimicrobial activity of bovine lactoperoxidase system," Journal of Food Protection, vol. 74, no. 1, pp. 134-139, 2011.

[25] A. N. Al-Baarri, M. Ogawa, and S. Hayakawa, "Application of lactoperoxidase system using bovine whey and the effect of storage condition on lactoperoxidase activity," International Journal of Dairy Science, vol. 6, no. 1, pp. 72-78, 2011.

[26] U. K. Laemmli, "Cleavage of structural proteins during the assembly of the head of bacteriophage T4," Nature, vol. 227, no. 5259, pp. 680-685, 1970.

[27] M. M. Bradford, "A rapid and sensitive method for the quantitation of microgram quantities of protein utilizing the principle of protein dye binding," Analytical Biochemistry, vol. 72, no. 1-2, pp. 248-254, 1976.

[28] M. M. Lang, L. J. Harris, and L. R. Beuchat, "Survival and recovery of Escherichia coli O157:H7, Salmonella, and Listeria 
monocytogenes on lettuce and parsley as affected by method of inoculation, time between inoculation and analysis, and treatment with chlorinated water," Journal of Food Protection, vol. 67, no. 6, pp. 1092-1103, 2004.

[29] M. Chigerwe and J. V. Hagey, "Refractometer assessment of colostral and serum IgG and milk total solids concentrations in dairy cattle," BMC Veterinary Research, vol. 10, no. 1, p. 178, 2014.

[30] A. Atasever, H. Ozdemir, I. Gulcin, and O. Irfan Kufrevioglu, "One-step purification of lactoperoxidase from bovine milk by affinity chromatography," Food Chemistry, vol. 136, no. 2, pp. 864-870, 2013.

[31] L. M. Wolfson and S. S. Sumner, "Antibacterial activity of the lactoperoxidase system: a review," Journal of Food Protection, vol. 56, no. 10, pp. 887-892, 1993.

[32] I. Van Opstal, C. F. Bagamboula, T. Theys, S. C. M. Vanmuysen, and C. W. Michiels, "Inactivation of Escherichia coli and Shigella in acidic fruit and vegetable juices by peroxidase systems," Journal of Applied Microbiology, vol. 101, no. 1, pp. 242-250, 2006.

[33] S. Z. Shariat and Z. Aghelan, "Partial purification and biochemical characterization of peroxidase from rosemary (Rosmarinus officinalis L.) leaves," Advanced Biomedical Research, vol. 4, no. 1, p. 159, 2015.

[34] P. K. Singh, H. V. Sirohi, N. Iqbal et al., "Structure of bovine lactoperoxidase with a partially linked heme moiety at $1.98 \AA$ resolution," Biochimica et Biophysica Acta (BBA) - Proteins and Proteomics, vol. 1865, no. 3, pp. 329-335, 2017.

[35] S. Lara-Aguilar and S. D. Alcaine, "Lactose oxidase: A novel activator of the lactoperoxidase system in milk for improved shelf life," Journal of Dairy Science, vol. 102, no. 3, pp. 1933-1942, 2019. 


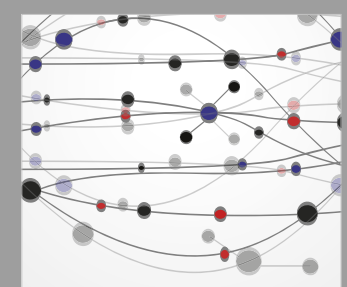

The Scientific World Journal
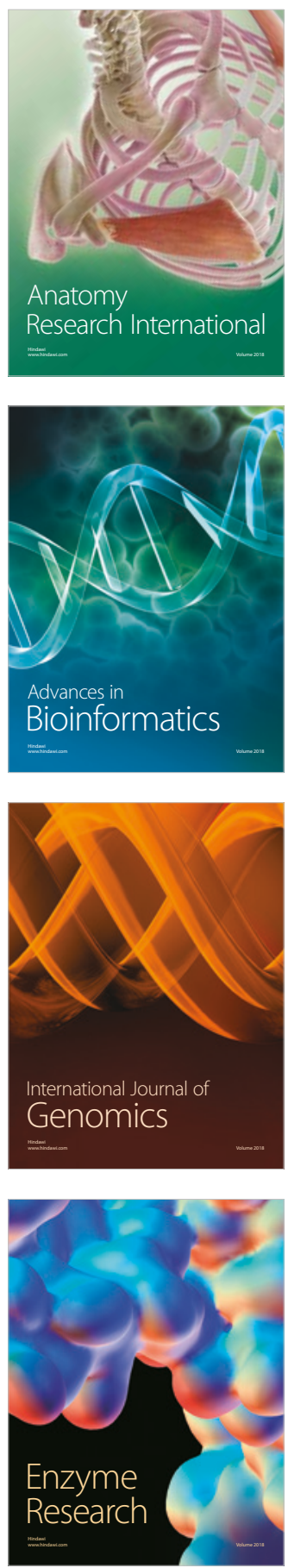
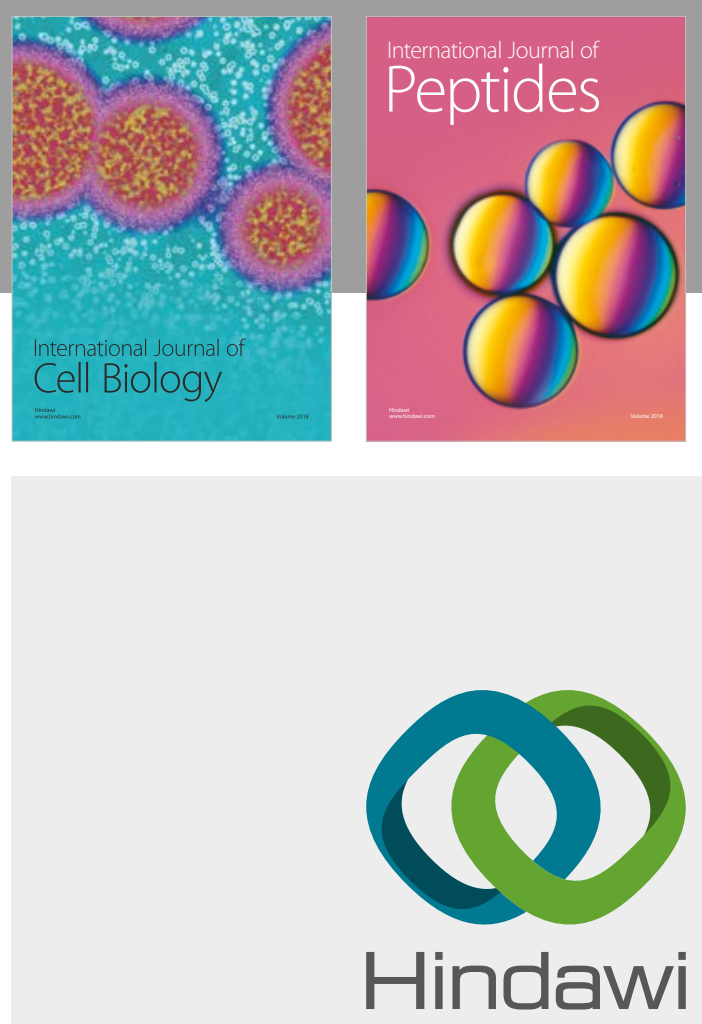

Submit your manuscripts at

www.hindawi.com
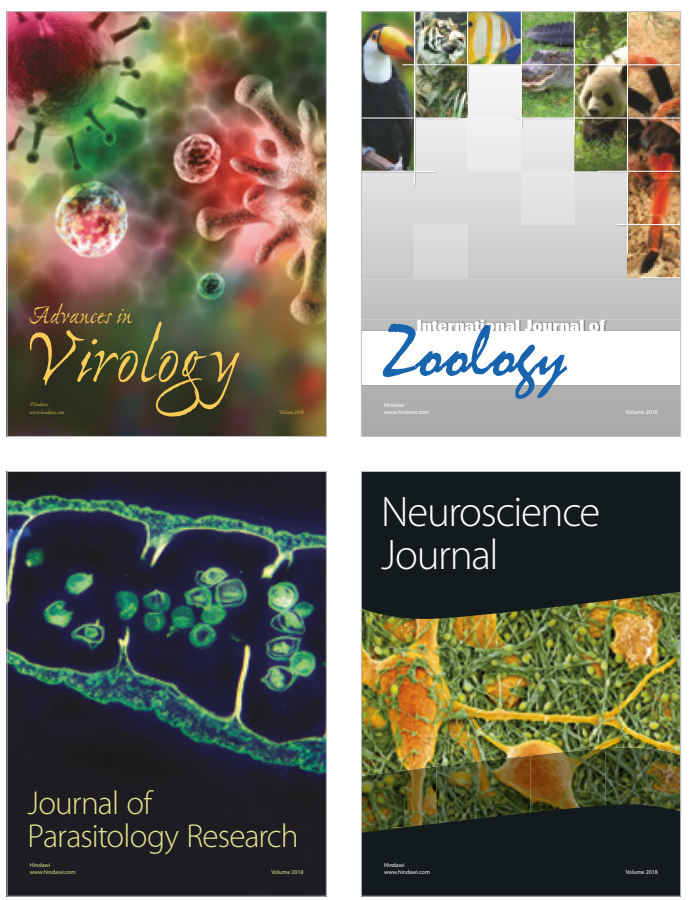
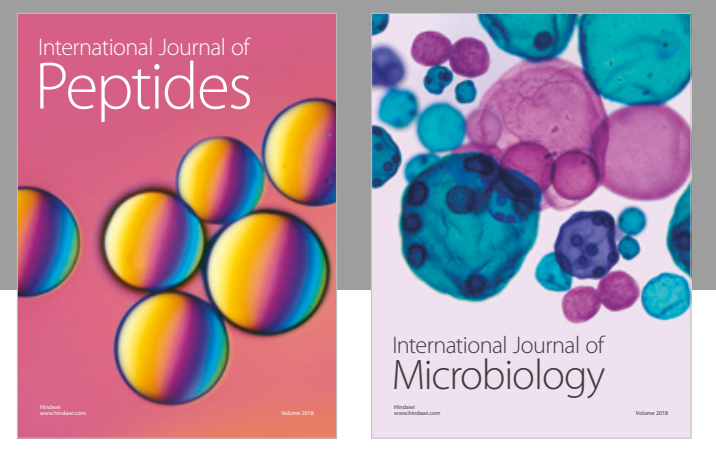

nternational Journal of Microbiology
Journal of
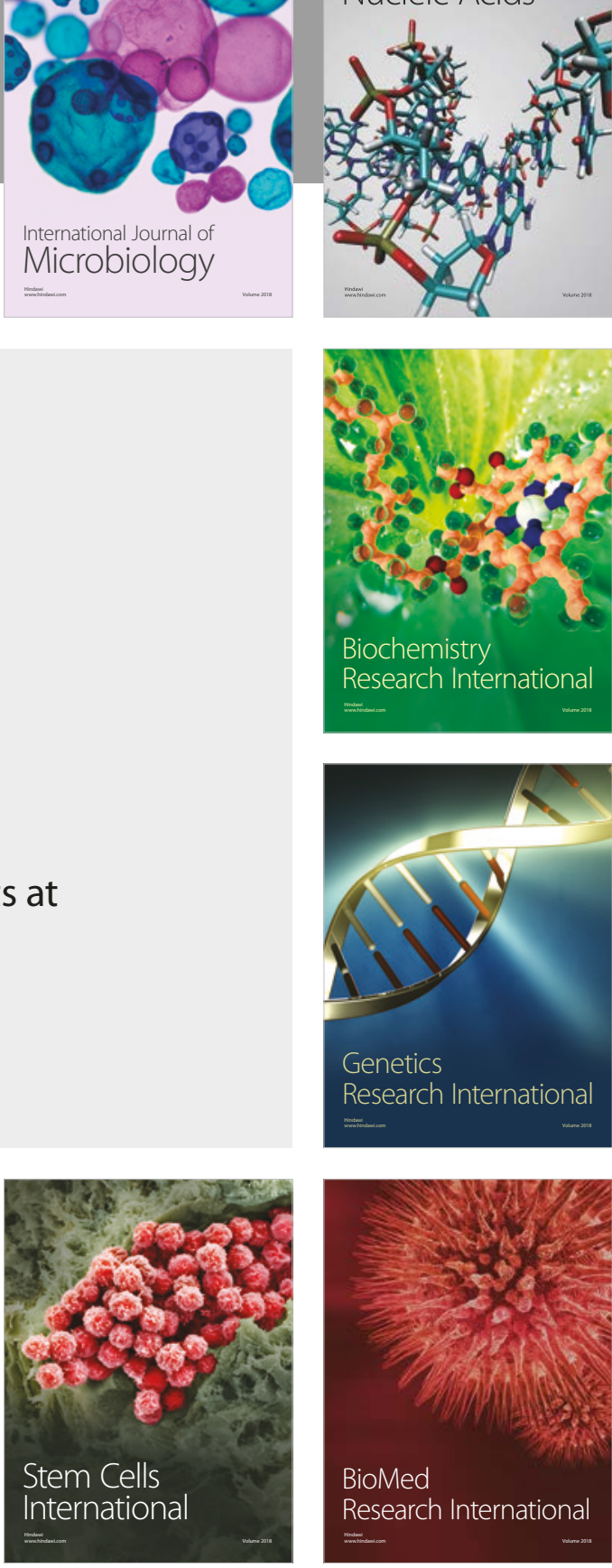
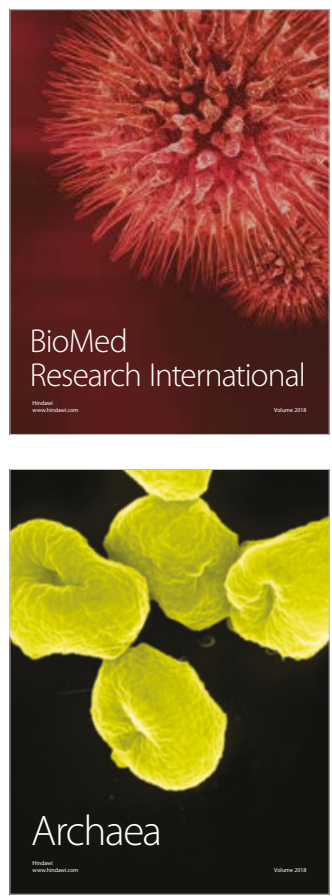